\title{
Evaluation of Antibacterial Activity and Antioxidant Potential of Different Extracts from the Leaves of Juniperus Phoenicea
}

\author{
Maraia F. Elmhdwi ${ }^{1 *}$, Idress Hamad Attitalla ${ }^{2}$, Barkat Ali Khan ${ }^{3}$ and Farid Menaa ${ }^{4}$ \\ ${ }^{1}$ Department of Chemistry (Biochemistry), Faculty of Science, Benghazi, University, Benghazi, Libya \\ ${ }^{2}$ Omar Al-Mukhtar University, Faculty of Science, Microbiology Department, Box 919, Al-Bayda, Libya \\ ${ }^{3}$ Faculty of Pharmacy, Gomal University, Dera Ismail khan, Pakistan \\ ${ }^{4}$ Department of Pharmaceutical Sciences Fluorotronics, Inc., USA
}

\begin{abstract}
Medicinal plants have recently received the attention of the antimicrobial activity of plants and their metabolites due to the challenge of growing incidents of drug-resistant pathogens. The aims of this study were to determine the antibacterial activities of the three extract (70\% methanol, $70 \%$ ethanol and $70 \%$ acetone) from leaves of Juniperus phoenicea. Also effect as antioxidant of different extracts. For each solvent, content of total phenolics and flavonoids were quantified. Antioxidant activity of different extracts were screened using the ferric reducing power and 1 , 1-diphenyl-2-picrylhydrazyl ( $\mathrm{DPPH}^{*}$ ) radical scavenging. The results showed that $70 \%$ acetone is the best solvent for the extraction of total phenolics, flavonoids, scavenging activity and have exhibited the higher reducing power. The antibacterial activity of the three extractions from leaves of Juniperus phoenicea was evaluated against five bacterial strains. The results showed that all extracts of Juniperus phoenicea leaves at concentration of $20 \%, 30 \%$ and $40 \%$ were effective against both Gram-positive and Gram-negative bacteria. We suggest the three extraction solvents of Juniperus phoenicea leaves were rich in phenolic constituents. Our investigation allows us to support that Juniperus phoenicea has the antioxidant activity and is effective against all Gram-positive and Gram-negative bacteria.
\end{abstract}

Keywords: Juniperus phoenicea; Antibacterial activity; Antioxidant activity

\section{Introduction}

In the last years, scientists have focused on increasing human infections caused by pathogen bacteria and fungi. Microorganisms have unfavorable effects on the quality and safety of life. Synthetic chemicals are widely used against these microorganisms; unfortunately, they develop resistance to many antibiotics due to the indiscriminate use of commercial antibiotics [1]. In addition, these antibiotics sometimes cause allergic reaction and immunity suppression. Currently, people heal a lot and although in many cases they are turning to synthetic drugs, but a vast majority is turning to natural products. Therefore the use of essential oils is less damaging to the human health [2] because they are generally few toxic and they do not have side effects. On the other hand, the food industry at present is facing a tremendous pressure from consumers for using chemical preservatives to prevent the growth of food borne and spoiling microbes. To reduce or eliminate chemically synthesized additives from foods is a current demand worldwide. A new approach to prevent the proliferation of microorganisms is the use of essential oils as preservatives. Essential oils of plants are of growing interest both in the industry and scientific research because of their antibacterial and antifungal properties and make them useful in many applications, including raw and processed food preservation, pharmaceuticals, alternative medicine and natural therapies [3].

The species Juniperus phoenicea is considered as an important medicinal plant largely used in traditional medicine. Its leaves are used in the form of decoction to treat diarrhea, rheumatism [4] and diabetes [5]. The mixture of leaves and berries of this plant is used as an oral hypoglycaemic agent [6], whereas the leaves are used against bronco-pulmonary disease and as a diuretic [4]. To the best of our knowledge, there are many papers report on the chemical composition of essential oils of $J$. phoenicea grown in north Mediterranean basin [710]. In the southern part of this later, few studies have investigated their antimicrobial activities [11-13]. The aim of this study was to determine the antimicrobial and antioxidant activity of leaves of juniperus phoenicea ssp. phoenicea extracts (methanol, Ethanol, and acetone) grows in Al-Jabal Al Akhdar.

\section{Materials and Methods}

\section{Materials}

Plant material: The leaves of Juniperus phoenicea ssp. phoenicea L, were collected from Al-Jabal Al Akhdar area in Benghazi, Libya (spring 2013).

Bacteria used: Bacteria were taken from the laboratory of microbiology in Banghazi medical center ,which know as multi drag resistant bacteria. The bacteria used were Escherichia coli (MDR)ATCC, Staphylococcus aureus(MDR) ATCC, Pseudomonas aeruginosa (MDR) ATCC, Klebsiella pneumonia (MDR) and Acinetobacter sp (MDR). The organisms were isolated and identified by standard methods, and identification confirmed by using phonex .The organisms were then sub cultured and maintained on nutrient agar slants.

Chemicals: 1,1-Diphenylpicrylhydrazyl (DPPH $\left.{ }^{\circ}\right)$, methanol, Ethanol and acetone were supplied from Sigma and Merck company. Ascorbic acid, Folin-Ciocalteu reagent, ferric chloride, potassium ferricyanide, monobasic dihydrogen phosphate, dibasic monohydrogen phosphate, trichloro acetic acid, sodium carbonate, anhydrous sodium

${ }^{*}$ Corresponding author: Maraia F. Elmhdwi, Department of Chemistry (Biochemistry), Faculty of Science, Benghazi University, Benghazi, Libya, Tel: +218913998351; E-mail: faragmaria20@gmail.com

Received August 10, 2015; Accepted September 16, 2015; Published September 22, 2015

Citation: Elmhdwi MF, Attitalla IH, Khan BA (2015) Evaluation of Antibacterial Activity and Antioxidant Potential of Different Extracts from the Leaves of Juniperus Phoenicea. J Plant Pathol Microb 6: 300. doi:10.4172/2157-7471.1000300

Copyright: @ 2015 Elmhdwi MF, et al. This is an open-access article distributed under the terms of the Creative Commons Attribution License, which permits unrestricted use, distribution, and reproduction in any medium, provided the original author and source are credited. 
Citation: Elmhdwi MF, Attitalla IH, Khan BA (2015) Evaluation of Antibacterial Activity and Antioxidant Potential of Different Extracts from the Leaves of Juniperus Phoenicea. J Plant Pathol Microb 6: 300. doi:10.4172/2157-7471.1000300

sulfate and pyrogallol were obtained from the biochemistry laboratory of chemistry department-Benghazi University.

\section{Methods}

Extraction of Juniperus phoenicea: The extract was obtained by macerating $30 \mathrm{~g}$ of the dried leaves from Juniperus phoenicea separately in methanol $(300 \mathrm{~mL} / \mathrm{L})$ for $48 \mathrm{~h}$. The resultant extract was filtered, concentrated to dryness in a rotary evaporator under reduced pressure at $40^{\circ} \mathrm{C}$, and then stored at $-8^{\circ} \mathrm{C}$ until use. Ethanol, and acetone were obtained by similar method as methanol extract.

Antioxidant activities assays and quantitative analysis: All of these experimental have been conducted in biochemistry laboratory at Benghazi University.

Total phenolic content (TPC): Total concentration of phenolic compound in all extracts obtained from leaves of $J$. phoenicea was estimated using the colorimetric method based on Folin-Ciocalteu reagent [14]. Quantification was done with respect to standard calibration curve of Pyrogallol the results were expressed as pyrogallol $" \mu \mathrm{g} / \mathrm{ml} "$. Estimation of the phenolic compounds was carried out in triplicate.

Total flavonoids content (TFC): Aluminum chloride colorimetric method were used for determination [15]. The calibration curve was obtained by preparing different quercetin solutions in methanol at concentrations "100 to $500 \mu \mathrm{g} / \mathrm{ml}$.

Reducing power assay (RPA): The reducing power were determined according to the Naznin and Hasan, [16]. Quantification was done with respect to stander calibration curve of ascorbic acid the results were expressed as ascorbic acid " $\mu \mathrm{g} / \mathrm{ml}$.

DPPH free radical scavenging activity (RSA): The antioxidant activity of the all extracts were measured in terms of hydrogen donating or radical-scavenging ability using the stable DPPH 'method as modified by Park et al. [17]. When the DPPH ${ }^{-}$reacted with an antioxidant compound in different extracts that can donate hydrogen, it was reduced and resulting decrease in absorbance at $517 \mathrm{~nm}$ using UV-visible spectrophotometer, and the mean values were obtained from triplicate experiments. The percentage of the remaining $\mathrm{DPPH}^{\circ}$ was plotted against the sample concentration. A lower value indicates greater antioxidant activity. Radical scavenging activity was expressed as percent of inhibition and was calculated using the following formula:-

\%DPPH "RSA"=[Abs. of Control-Abs. of Sample/Abs. of Control] $\times 100$

Antibacterial activities of different extracts leaves from the Juniperus phoenicea: In this study diluted of extracts leaves from the Juniperus phoenicea were used. The diluted extracts leaves were prepared by using Dimethyl Sulfoxide (DMSO) to obtain 20\% (v/v), $30 \%(\mathrm{v} / \mathrm{v})$ and $40 \%(\mathrm{v} / \mathrm{v})$ concentrations. DMSO was used as negative control. The antibacterial activity of each extracts were tested by Hole diffusion method [18]. Muller Hinton agar plates were inoculated by rubbing sterile cotton swabs after immerse $100 \mu \mathrm{l}$ bacterial suspensions on plates (overnight cultures grown at $37^{\circ} \mathrm{C}$ on nutrient agar and adjusted to $0.5 \mathrm{McF}$ arland in sterile saline) over the entire surface of the plate. After inoculation, $9 \mathrm{~mm}$ diameter wells were cut into the surface of the agar using a sterile cork borer. Different concentrations $(20 \%, 30 \%$ and $40 \%$ ) were added to the wells. Plates were incubated at $37^{\circ} \mathrm{C}$ for $24 \mathrm{~h}$. Control wells contained DMSO. Bacterial growth inhibition was determined as the diameter of the inhibition zones around the discs. Zones of inhibition were measured by using ruler .The diameter of zones was recorded. Each assay was carried out in triplicate .The effect of different extracts on the tested bacteria was compared with the sensitivity of the same bacteria to five antibiotics (Colisti sulphate, Amicacin, Amoxycillin, gentamicin and sulphamethoxazole trimethoprim).

\section{Results and Discussion}

Antioxidant evaluation of essential oils extracted from Juniperus phoenicea ssp: The antioxidant activities of all extracted of leaves Juniperus phoenicea grows are evaluated by:

Total phenolic content (TPC) and total flavonoids content (TFC): Data in figure 1 showed that total phenolic content found in methanol, ethanol and acetone extracted from leaves Juniperus phoenicea grows in Al-Jabal Al Akhdar were (1.361, 2.21 and 2.69 at 500 $\mu \mathrm{g} / \mathrm{ml}$ Concentration) respectively ,the results expressed according to pyrogallol as phenolic compound (2.105) at $500 \mu \mathrm{g} / \mathrm{ml}$ Concentration. The total flavonoid of methanol, ethanol and acetone extracted from leaves Juniperus phoenicea were $(1.266,1.340$ and 1.690 at $500 \mu \mathrm{g} / \mathrm{ml}$ Concentration) respectively as compared with the qurecetin (1.300 at $500 \mu \mathrm{g} / \mathrm{ml}$ Concentration) (figure 2). The results of the current study using the juniper phoenicea correlated with the findings of other investigators $[19,20]$. Phenols and polyphenolic compounds such as flavonoids are widely found in food products derived from plant sources and they have been shown to poses significant antioxidant activities [21]. Acetone extracted showed high total phenol and flavonoid contents. This result is consistent with the findings of Mansouri et al. [19] who studied the total phenolic content and antioxidant activity of three Juniperus phoenicea extracts methanol, hexane and acetone, and found the highest extraction rate of phenolic compounds for Juniperus phoenicea was obtained by acetone.

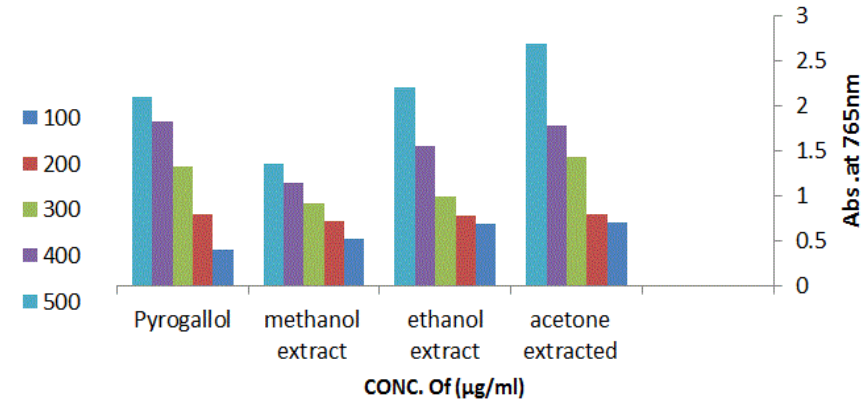

Figure 1: Total phenolic content (TPC) of methanol, ethanol and acetone extracted from leaves Juniperus grow in Al-Jabal Al Akhdar and pyrogallol as phenolic compound.

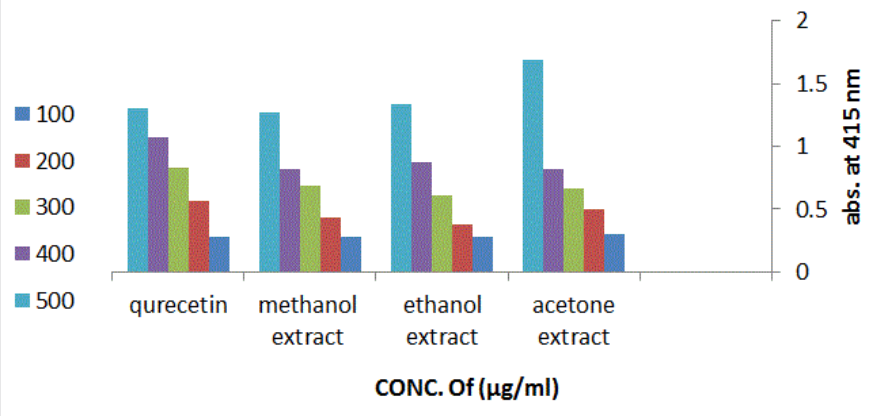

Figure 2: Total flavonoids content of methanol, ethanol and acetone extracted from leaves Juniperus grow in Al-Jabal Al Akhdar and qurecetin as flavonoid compound. 
Reducing power assay (RPA) and The $\mathrm{DPPH}^{\circ}$ radical scavenging activity: The reducing power assay is associated with antioxidant activity and may serve as a significant reflection of the antioxidant activity. Compounds with reducing power indicate that they are electron donors and can reduce the oxidized intermediates. In this, assay the yellow colour of the test solution change to various shades of green and blue depending on the reducing power of each compound. Presence of the reducers causes the conversion of the ferricyanide to the ferrous form [22]. Figure 3 shows the reducing power assay of the methanol, ethanol and acetone extracts from leaves Juniperus phoenicea. The reducing power assay increase with increase in concentration and the acetone extract exhibit higher reducing activity than the ethanol and methanol extracts .

$\mathrm{DPPH}^{\cdot}$ radical scavenging activity assay assessed the ability of the extract to donate hydrogen or to scavenge free radicals. DPPH radical is a stable free radical and when it reacts with an antioxidant compound which can donate hydrogen, it is reduced to diphenylpicrylhydrazine. The changes in colour (i.e. from deep-violet to light-yellow) can be measured spectrophotometrically [23].

The all extracts when mixed with the DPPH decolorized it due to hydrogen donating ability, it was observed that the scavenging activity of acetone extract at all concentrations from 100 to $500 \mu \mathrm{g} / \mathrm{ml}$ is rather strong than the ethanol and methanol extracts. Table 1 show the radical scavenging activity of acetone, ethanol and methanol extracts. Ascorbic acid, which used as standard antioxidant. Fatma and Violet [24] found that essential oils of Juniperus phoenicea had the highest radicalscavenging activity followed by all medicinal Plants.

The genus Juniperus is an important component of arid and semi-arid ecosystems throughout the northern hemisphere $[25,26]$. Previously, from the genus Juniperus some terpenoids have been isolated [17,27], neolignans [28] and flavonoids [29].The species of Juniperus is considered as an important medicinal plant largely used in traditional medicine. The anti-inflammatory activity of some diterpenoids of Leaves juniperus [27] and several studies about the essential oil of Leaves juniperus have been published [26]. All oils of Juniperus phoenicea of five localities from eastern Algeria have a high content of $\alpha$-pinene, $\Delta 3$-carene, limonene, terpinolene and the a-terpinyl acetate [30].

The phenolic and the flavonoids compounds are groups of secondary metabolites with broad range of biological properties such as: antioxidant, antibacterial ,anti-atherosclerosis, cardiovascular protection and improvement of the endothelial function, it has been reported that antioxidant activity of the phenolic compounds is mainly due to their redox properties which allow them to act as reducing agents, hydrogen donors play an important role by adsorbing and neutralizing reactive free radicals, and chelating ferric ions which catalyses lipid peroxidation, and regarded as promising therapeutic agent for free radical-linked pathologies [31].

\section{Antibacterial activity assay:}

The results of the well diffusion test revealed that the all extracts of leaves from juniper phoenicea shows a significant activity on bacteria tested with varying degrees of inhibition of growth, depending on the bacterial strains (Tables 2-4), antibiotic activity of different type of bacteria as compare to the standard (Table 5). These results agree with that obtained by Malu et al. [32].

In the present study, the results for the antibacterial screening have shown that extract of acetone from juniperus phoenicea significantly inhibit E. coli compared to other extracts (figure 5). This result agrees with that obtained by Ekweny and Elegalam [33], who reported that juniper phoenicea inhibit E. coli. Also, Malu et al. [32] reported that juniper phoenicea extracts possesses antibacterial properties and could be used for the treatment of bacterial infections.

This study showed that acetone extracted from juniper phoenicea was more effective against staphylococcus aurius bacteria than Ps. aeruginosa bacteria in vitro with zones of inhibition ranging from (16 $\mathrm{mm}$ to $19 \mathrm{~mm}$ )and ( $8 \mathrm{~mm}$ to $12 \mathrm{~mm}$ ) respectively (Table 2) (Figures 6 and 7). In contrast several studies that Ps. aeruginosa more resistant against (essential oils) because of the cell wall structure. Gram-negative bacteria have an outer lipopolysaccharide wall that can work as a barrier against toxic agents [34], which is similar to other reports describing the use of essential oils components [35-37].

The methanol and ethanol extracts from juniper phoenicea (Tables 3 and 4) are more effective against Staphylococcus aurius bacteria at $40 \%$ concentration) (Figures 12 and 16), which is similar to reported by Mazari et al. [38]. It has been shown that Gram-positive bacteria are more sensitive than Gram-negative as was shown by Ait Ouazzou et al. [39].

chemical composition of the essential oil of $J$. Phoenicea is dominated by the presence of a major product, $\alpha$-pinene with an average (48.08\%), terpinolene (13\%) and $\Delta 3$-carene(12.4\%) [19], which is an antimicrobial compound having wide spectra of antimicrobial effects against enter bacteria. Similar findings have been reported by other investigators $[30,40]$. The results of the current study using the juniper phoenicea correlated with the findings of other investigators Amer et al. [6] and Barrero et al. [17]. Massoud et al. [30] showed antimicrobial activity of essential oils of J. phoenicea against nine bacteria.

Natural plant antioxidants include phenolic compounds may produce beneficial effects by scavenging free radicals [15]. Thus, phenolic compounds may help protect cells against the oxidative damage caused by free radicals, Korakot et al. [41] reported that the extract plant rich in phenolic compounds leads to antibacterial activity.

\section{Conclusion}

Antibacterial activities of these extracts were due to abundance of the $\alpha$-pinene and overall chemical constituents of these extracts. The antibacterial activity besides several biological activities can be employed in place of costly antibiotics for effective control of food borne pathogens. Juniperus phoenicea leaves can be a source of antibacterial drugs against gram-positive bacteria, especially against multi-resistant microorganisms, but it is further research still required.

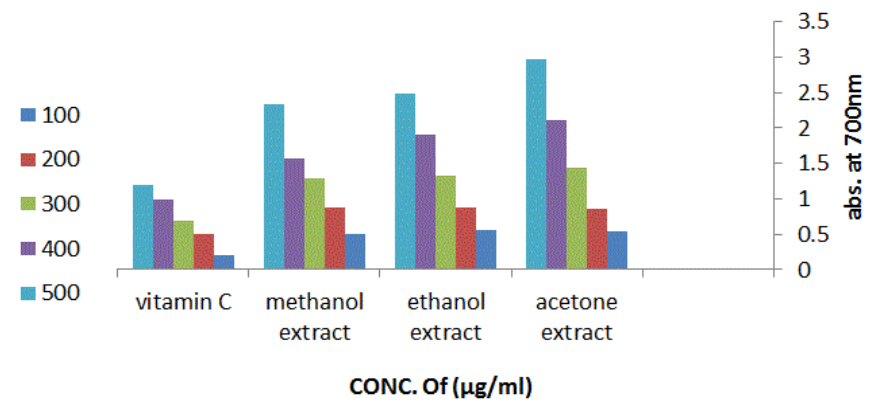

Figure 3: Reducing power assay of methanol, ethanol and acetone extracted from leaves Juniperus grow in Al-Jabal Al Akhdar and vitamin C. 
Citation: Elmhdwi MF, Attitalla IH, Khan BA (2015) Evaluation of Antibacterial Activity and Antioxidant Potential of Different Extracts from the Leaves of Juniperus Phoenicea. J Plant Pathol Microb 6: 300. doi:10.4172/2157-7471.1000300

Page 4 of 8

\begin{tabular}{|c|c|c|c|c|c|c|c|}
\hline $\begin{array}{l}\text { Concentration of } \\
\text { vitamin C } \\
" \mu \mathrm{g} / \mathrm{ml} "\end{array}$ & $\begin{array}{c}\text { Percent of } \\
\text { inhibition (\%) }\end{array}$ & $\begin{array}{c}\text { concentration of } \\
\text { methanol extracted } \\
\text { from leaves Juniperus } \\
\quad \mu \mathrm{g} / \mathrm{ml}\end{array}$ & $\begin{array}{c}\text { Percent of } \\
\text { inhibition (\%) }\end{array}$ & $\begin{array}{c}\text { concentration of } \\
\text { ethanol extracted } \\
\text { from leaves } \\
\text { Juniperus } \\
" \mu \mathrm{g} / \mathrm{ml} "\end{array}$ & $\begin{array}{c}\text { Percent of } \\
\text { inhibition (\%) }\end{array}$ & $\begin{array}{l}\text { concentration of } \\
\text { acetone extracted } \\
\text { from leaves } \\
\text { Juniperus } \\
" \mu \mathrm{g} / \mathrm{ml} "\end{array}$ & $\begin{array}{c}\text { Percent of } \\
\text { inhibition (\%) }\end{array}$ \\
\hline 100 & $72.3 \%$ & 100 & $37 \%$ & 100 & $39 \%$ & 100 & $39 \%$ \\
\hline 200 & $80.8 \%$ & 200 & $59 \%$ & 200 & $59 \%$ & 200 & $73 \%$ \\
\hline 300 & $89.1 \%$ & 300 & $70 \%$ & 300 & $75 \%$ & 300 & $77 \%$ \\
\hline 400 & $92.8 \%$ & 400 & $83 \%$ & 400 & $87 \%$ & 400 & $89 \%$ \\
\hline 500 & $96.7 \%$ & 500 & $92 \%$ & 500 & $95 \%$ & 500 & $96 \%$ \\
\hline
\end{tabular}

Table 1: DPPH radical scavenging activity of vitamine C, methanol, ethanol and acetone extracted from leaves Juniperus grow in Al-Jabal Al Akhdar according to \% inhibition.

\begin{tabular}{|c|c|c|c|}
\hline \multirow{3}{*}{ Bacteria } & \multicolumn{3}{|c|}{ Zone of inhibition $\mathrm{mm} \pm$ standard deviation } \\
\hline & \multicolumn{3}{|c|}{ Concentration } \\
\hline & $20 \%$ & $30 \%$ & $40 \%$ \\
\hline Escherichia coli & $14 \mathrm{~mm} \pm 0.22$ & $17 \mathrm{~mm} \pm 0.05$ & $19 \mathrm{~mm} \pm 0.12$ \\
\hline Staphylococcus aureus & $16 \mathrm{~mm} \pm 0.04$ & $18 \mathrm{~mm} \pm 0.05$ & $19 \mathrm{~mm} \pm 0.15$ \\
\hline Pseudomonas aeruginosa & $8 \mathrm{~mm} \pm 0.17$ & $9 \mathrm{~mm} \pm 0.02$ & $12 \mathrm{~mm} \pm 0.03$ \\
\hline Acinetobacter sp & $15 \mathrm{~mm} \pm 0.11$ & $17 \mathrm{~mm} \pm 0.17$ & $18 \mathrm{~mm} \pm 0.12$ \\
\hline Klebsiella pneumonia & $18 \mathrm{~mm} \pm 0.09$ & $20 \mathrm{~mm} \pm 0.13$ & $22 \mathrm{~mm} \pm 0.11$ \\
\hline
\end{tabular}

Table 2: Antibacterial activity of Acetone extracted from juniper phoenicea. Each assay in these experiments was repeated three times and the results (mm of zone of inhibition) were expressed as average values ( \pm standard deviation). Mean inhibition zone diameter (mm) after $24 \mathrm{~h}$ of incubation.

\begin{tabular}{|c|c|c|}
\hline \multirow{2}{*}{ Bacteria } & \multicolumn{2}{|c|}{ Zone of inhibition mm \pm standard deviation } \\
\cline { 2 - 4 } & $\mathbf{2 0} \%$ & \multicolumn{2}{|c|}{ Concentration } \\
\cline { 2 - 4 } & $11 \mathrm{~mm} \pm 0.02$ & $12 \mathrm{~mm} \pm 0.11$ \\
\hline Escherichia coli & $15 \mathrm{~mm} \pm 0.09$ & $17 \mathrm{~mm} \pm 0.05$ \\
\hline Staphylococcus aureus & $11 \mathrm{~mm} \pm 0.22$ & $12 \mathrm{~mm} \pm 0.13$ \\
\hline Kseudomonas aeruginosa & $11 \mathrm{~mm} \pm 0.06$ & $12 \mathrm{~mm} \pm 0.13$ \\
\hline
\end{tabular}

Table 3: Antibacterial activity of methanol extracted from juniper phoenicea.

\begin{tabular}{|c|c|c|c|}
\hline \multirow{2}{*}{ Bacteria } & \multicolumn{2}{|c|}{ Zone of inhibition mm \pm standard deviation } \\
\cline { 2 - 4 } & $\mathbf{2 0} \%$ & $\mathbf{2}$ Concentration \\
\cline { 2 - 4 } & $10 \mathrm{~mm} \pm 0.21$ & $11 \mathrm{~mm} \pm 0.09$ \\
\hline Escherichia coli & $15 \mathrm{~mm} \pm 0.05$ & $18 \mathrm{~mm} \pm 0.12$ \\
\hline Pseudomonglococcus aureus & $11 \mathrm{~mm} \pm 0.13$ & $13 \mathrm{~mm} \pm 0.11$ \\
\hline Acinetobacter sp & $9 \mathrm{~mm} \pm 0.11$ & $14 \mathrm{~mm} \pm 0.05$ \\
\hline Klebsiella pneumonia & $11 \mathrm{~mm} \pm 0.07$ & $15 \mathrm{~mm} \pm 0.01$ \\
\hline
\end{tabular}

Table 4: Antibacterial activity of Ethanol extracted from juniper phoenicea.

\begin{tabular}{|c|c|c|c|c|}
\hline \multirow{2}{*}{ Bacteria } & \multicolumn{3}{|c|}{ Zone of Inhibition (mm) \pm Standard deviation } \\
\cline { 2 - 5 } & Colisti sulphate & Amicacin & Amoxycillin & Gentamycin \\
\hline Escherichia coli & - & $15 \mathrm{~mm} \pm 0.02$ & - & $0 \mathrm{~mm} \pm 0.031$ \\
\hline Staphylococcus aureus & $2 \mathrm{~mm} \pm 0.01$ & $13 \mathrm{~mm} \pm 0.02$ & $3 \mathrm{~mm} \pm 0.01$ & $-6 \mathrm{~mm} \pm 0.01$ \\
\hline Pseudomonas aeruginosa & $3 \mathrm{~mm} \pm 0.01$ & $9 \mathrm{~mm} \pm 0.01$ & - & $5 \mathrm{~mm} \pm 0.02$ \\
\hline Acinetobacter sp & $6 \mathrm{~mm} \pm 0.03$ & - & - & $3 \mathrm{~mm} \pm 0.00$ \\
\hline Klebsiella pneumonia & $4 \mathrm{~mm} \pm 0.01$ & $12 \mathrm{~mm} \pm 0.04$ & $2 \mathrm{~mm} \pm 0.01$ & - \\
\hline
\end{tabular}

Table 5: Antibiotic activity of different type of bacteria. 


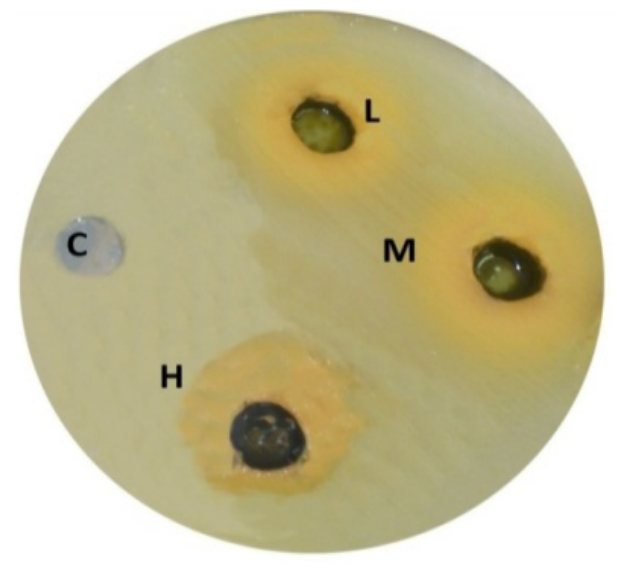

Figure 4: Antibacterial activity of acetone extracted from leave juniper phoenicea against Acinetobacter sp bacteria at $20 \%, 30 \%$ and $40 \%$ concentration

$\mathrm{C}=$ negative control $(\mathrm{DMSO}), \mathrm{L}=20 \%, \mathrm{M}=30 \%, \mathrm{H}=40 \%$.

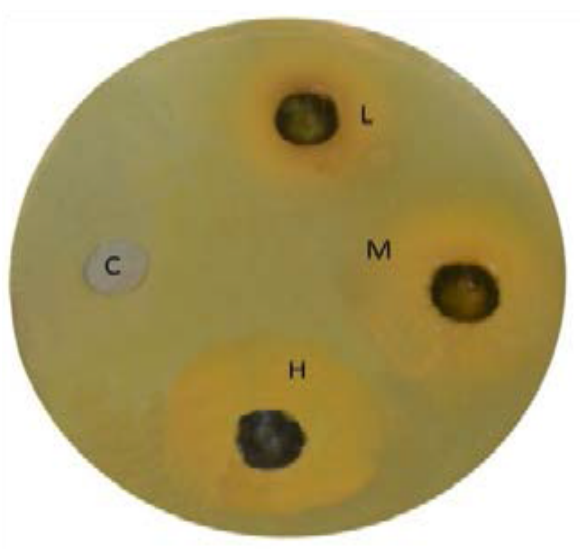

Figure 5: Antibacterial activity of acetone extracted from leave juniper phoenicea against E.coli bacteria at $20 \%, 30 \%$ and $40 \%$ concentration $\mathrm{C}=$ negative control (DMSO), $\mathrm{L}=20 \%, \mathrm{M}=30 \%, \mathrm{H}=40 \%$.

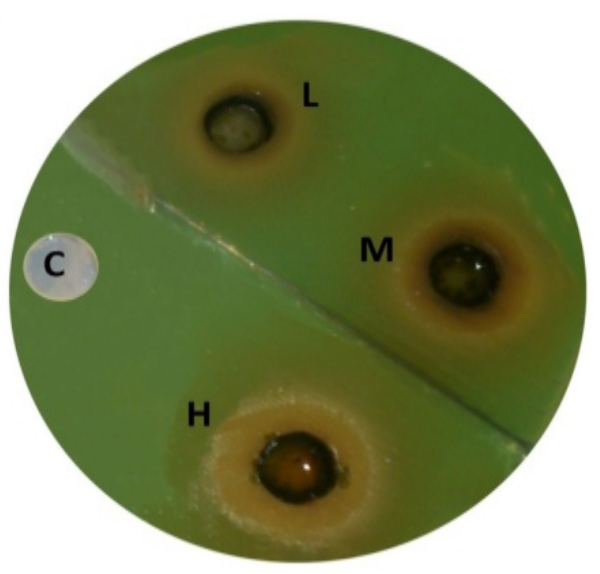

Figure 6: Antibacterial activity of acetone extracted from leave juniper phoenicea against $P$. aeruginosa bacteria at $20 \%, 30 \%$ and $40 \%$ concentration

$\mathrm{C}=$ negative control (DMSO), $\mathrm{L}=20 \%, \mathrm{M}=30 \%, \mathrm{H}=40 \%$.

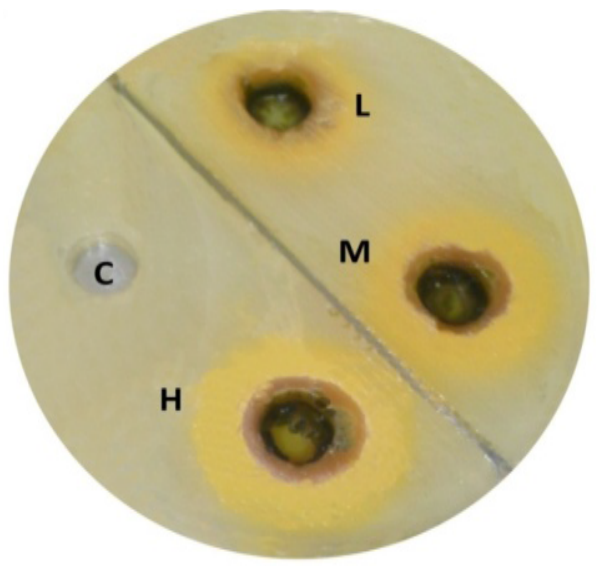

Figure 7: Antibacterial activity of acetone extracted from leave juniper phoenicea against Staphylococcus.arues bacteria at $20 \%, 30 \%$ and $40 \%$ concentration

$\mathrm{C}=$ negative control (DMSO), $\mathrm{L}=20 \%, \mathrm{M}=30 \%, \mathrm{H}=40 \%$.

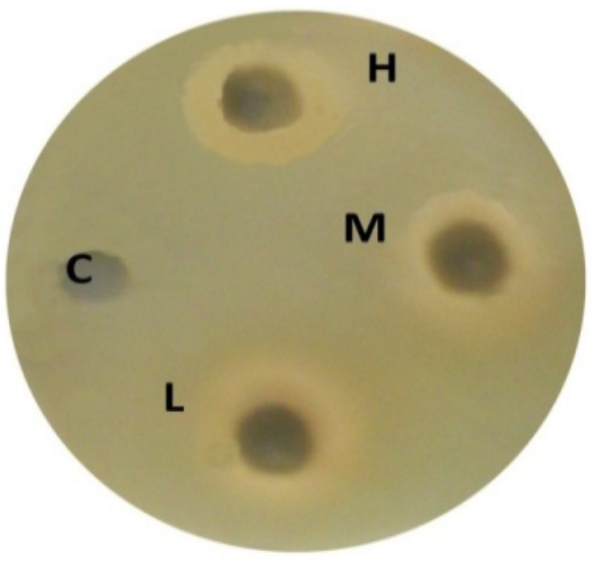

Figure 8: Antibacterial activity of methanol extracted from leave juniper phoenicea against Acinetobacter sp bacteria at $20 \%, 30 \%$ and $40 \%$ concentration

$\mathrm{C}=$ negative control (DMSO), $\mathrm{L}=20 \%, \mathrm{M}=30 \%, \mathrm{H}=40 \%$

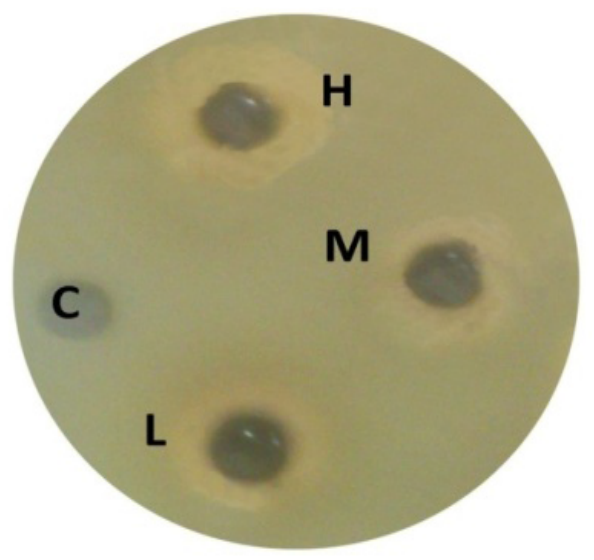

Figure 9: Antibacterial activity of methanol extracted from leave juniper phoenicea against E.coli bacteria at $20 \%, 30 \%$ and $40 \%$ concentration $\mathrm{C}=$ negative control $(\mathrm{DMSO}), \mathrm{L}=20 \%, \mathrm{M}=30 \%, \mathrm{H}=40 \%$ 
Citation: Elmhdwi MF, Attitalla IH, Khan BA (2015) Evaluation of Antibacterial Activity and Antioxidant Potential of Different Extracts from the Leaves of Juniperus Phoenicea. J Plant Pathol Microb 6: 300. doi:10.4172/2157-7471.1000300

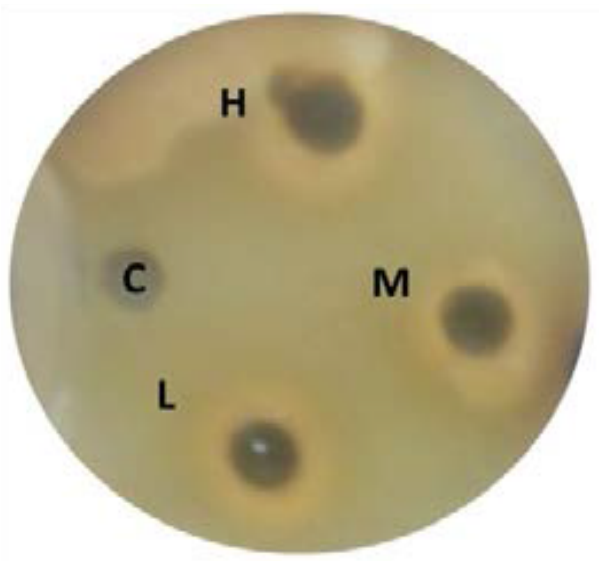

Figure 10: Antibacterial activity of methanol extracted from leave juniper phoenicea against Klebsella.pneumonia bacteria at $20 \%, 30 \%$ and $40 \%$ concentration

$\mathrm{C}=$ negative control (DMSO), $\mathrm{L}=20 \%, \mathrm{M}=30 \%, \mathrm{H}=40 \%$

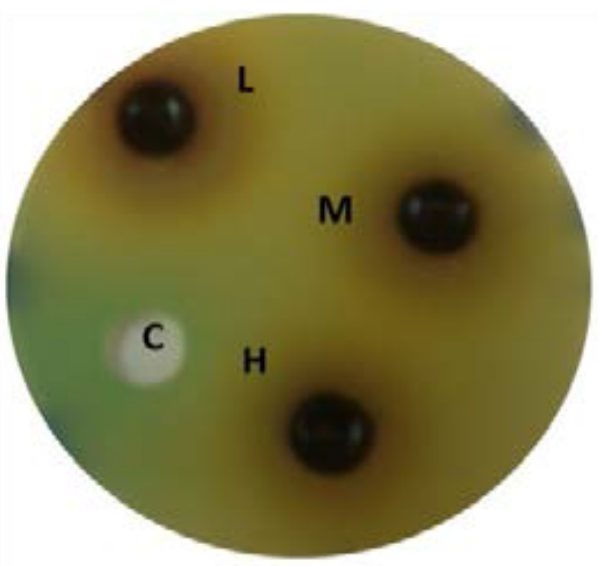

Figure 11: Antibacterial activity of methanol extracted from leave juniper phoenicea against $P$.aeruginosa bacteria at $20 \% 30 \%$ and $40 \%$ concentration.

$C=$ negative control (DMSO), $L=20 \%, M=30 \%, H=40 \%$.

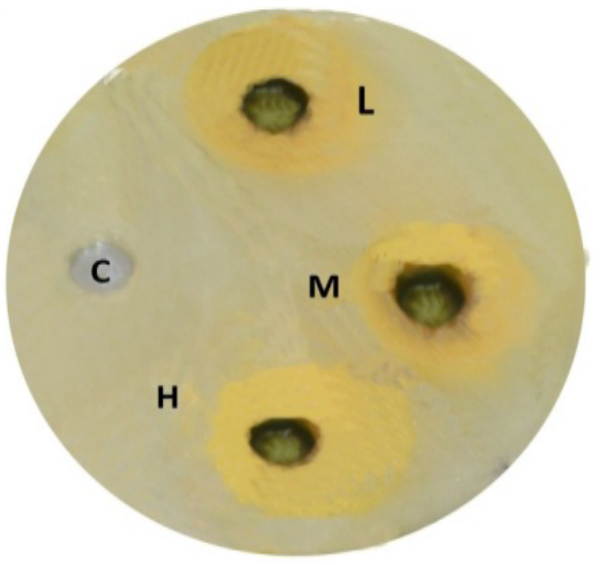

Figure 12: Antibacterial activity of methanol extracted from leave junipe phoenicea against Staphylococcus.arues bacteria at $20 \%, 30 \%$ and $40 \%$ concentration.

$\mathrm{C}=$ negative control (DMSO), $\mathrm{L}=20 \%, \mathrm{M}=30 \%, \mathrm{H}=40 \%$.

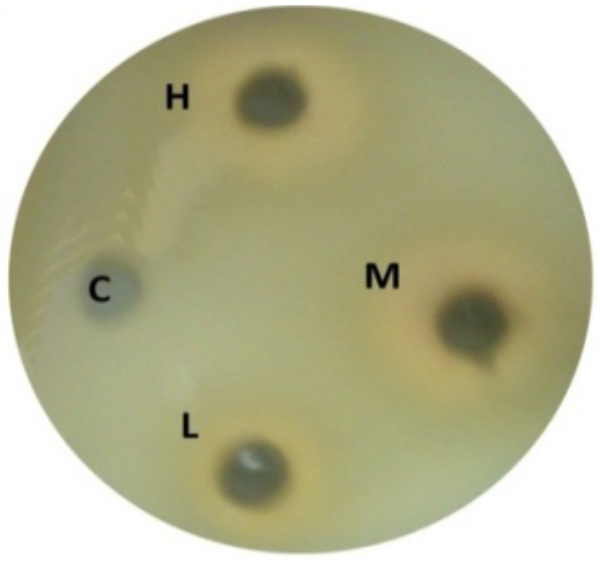

Figure 13: Antibacterial activity of ethanol extract of juniper phoenicea against Acinetobacter sp bacteria at $20 \%, 30 \%$ and $40 \%$ concentration $\mathrm{C}=$ negative control (DMSO), $\mathrm{L}=20 \%, \mathrm{M}=30 \%, \mathrm{H}=40 \%$.

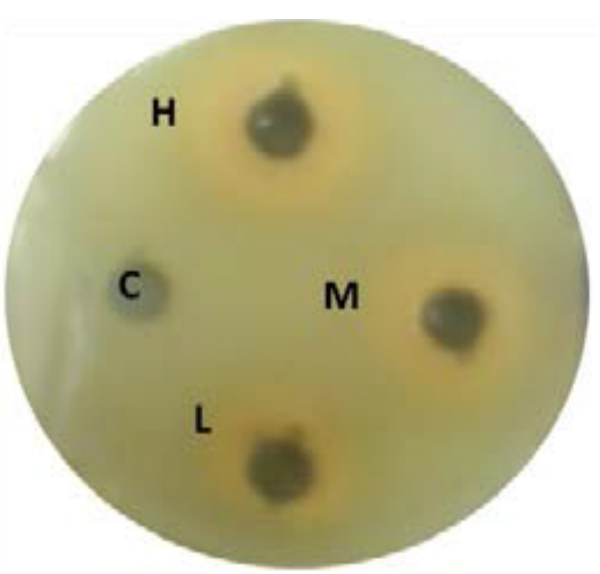

Figure 14: Antibacterial activity of ethanol extract juniper phoenicea against Klebsella. pneumonia bacteria at $20 \%, 30 \%$ and $40 \%$ concentration $\mathrm{C}=$ negative control (DMSO), $\mathrm{L}=20 \%, \mathrm{M}=30 \%, \mathrm{H}=40 \%$.

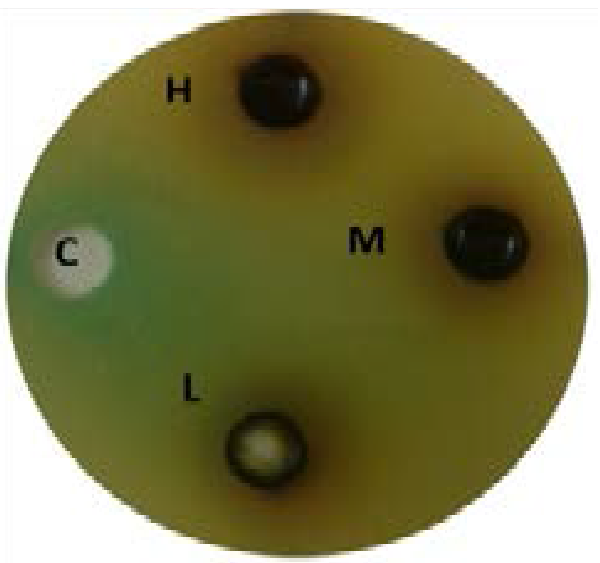

Figure 15: Antibacterial activity of ethanol extract of juniper phoenicea against $P$.aeruginosa bacteria at $20 \%, 30 \%$ and $40 \%$ concentration $\mathrm{C}=$ negative control (DMSO), $\mathrm{L}=20 \%, \mathrm{M}=30 \%, \mathrm{H}=40 \%$ 
Citation: Elmhdwi MF, Attitalla IH, Khan BA (2015) Evaluation of Antibacterial Activity and Antioxidant Potential of Different Extracts from the Leaves of Juniperus Phoenicea. J Plant Pathol Microb 6: 300. doi:10.4172/2157-7471.1000300

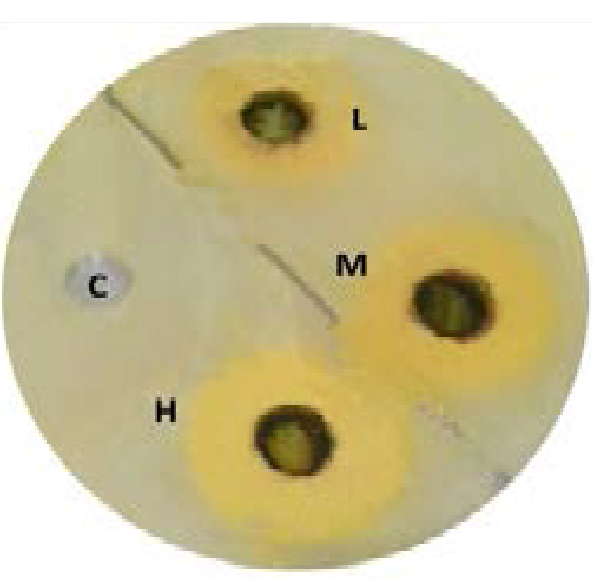

Figure 16: Antibacterial activity of ethanol extract of juniper phoenicea against Staphylococcus.arues bacteria at $20 \%, 30 \%$ and $40 \%$ concentration $\mathrm{C}=$ negative control $(\mathrm{DMSO}), \mathrm{L}=20 \%, \mathrm{M}=30 \%, \mathrm{H}=40 \%$.

\section{References}

1. Khadidja M, Nassima B, Chahrazed B, Xavier F (2010) Chemical composition and antimicrobial activity of essential oils isolated from Algerian Juniperus phoenicea L. and Cupressus sempervirens L. Journal of Medicinal Plants Research 4: 959-964.

2. Isman MB (2000) Plant essential oils for pest and disease management. Crop Prot 19: 603-608.

3. Lis-Balchin M, Deans SG (1997) Bioactivity of selected plant essential oils against Listeria monocytogenes. J Appl Microbiol 82: 759-762.

4. Bellakhder J (1997) La Pharmacopée Marocaine traditionnelle. Paris: Ibis Press p. 272.

5. Allali H, Benmehdi H, Dib MA, Tabti B, Ghalem S, et al. (2008) Phytotherapy of diabetes in West Algeria. Asian J Chem 20: 2701- 2710.

6. Amer M, Wasif M, Abo-Aytta A (1994) Chemical and biological evaluation of Juniperus phoenicea as a hypoglycaemic agent. J Agric Res 21: 1077-1091.

7. Chanegriha N, Baâliouamer A, Meklati B, Favre-Bonvin J, Alamercery S (1993) Chemical composition of Algerian cypress essential oil. J Essent Oil Res 5: 671-674

8. Chanegriha N, Baâliouamer A, Meklati B, Chretien J, Keravis G (1997): GC and GC/MS leaf oil analysis of four Algerian cypress species. J Essent Oil Res 9: 555-559.

9. Rezzi S, Cavaleiro C, Bighelli A, Salgueiro L, da Cunha AP, et al. (2001) Intraspecific chemical variability of the leaf essential oil of Juniperus phoenicea subsp. turbinata from Corsica. Biochem Syst Ecol 29: 179-188.

10. Tapondjou AL, Adler C, Fontem DA, Bouda H, Reichmuth C (2005) Bioactivities of cymol and essential oils of Cupressus sempervirens and Eucalyptus saligna against Sitophilus zeamais Motschulsky and Tribolium confusum du Val. J Stored Prod Res 41: 91-102.

11. Stassi V, Verykokidou E, Loukis A, Harvala C, Philianos S (1996) The antimicrobial activity of the essential oils of four Juniperus species growing wild in Greece. Flav Fragr J 11: 71-74

12. Angioni A, Barra A, Russo MT, Coroneo V, Dessi S, et al. (2003) Chemical composition of the essential oils of Juniperus from ripe and unripe berries and leaves and their antimicrobial activity. J Agric Food Chem 51: 30733078 .

13. Derwich E, Benziane Z, Boukir A (2010) Chemical Composition of Leaf Essential Oil of Juniperus phoenicea and Evaluation of its Antibacterial Activity. International journal of agriculture \& biology 12: 199-204.

14. Chia-Ching L, En-Shyh L (2010) Antiradical capacity and reducing power of different extraction method of Areca catechu seed. African Journal of Biotechnology 9: 7831-7836.
15. Chang M, Meiwen $\mathrm{H}$, Chern J (2002) Estimation of Total Flavonoid Content in Propolis by Two Complementary Colorimetric Methods, Journal of Food and Drug Analysis 10: 178-182.

16. Naznin A, Hasan N (2009) In vitro antioxidant activity of methanolic Leaves and Flowers extracts of Lippia Alba. Journal of Medicine and Medical Sciences 4 107-110.

17. Barrero A, Herrador M, Arteaga P, Quilez F, Sanchez E, et al. (2006) Chemical composition of the essential oil from the leaves of Juniperus phoenicea $\mathrm{L}$. from North Africa. J Essent Oil Res 18: 168-169.

18. Al Somal N, Coley KE, Molan PC, Hancock BM (1994) Susceptibility of Helicobacter pylori to the antibacterial activity of manuka honey. J R Soc Med 87: 9-12.

19. Mansouri N, Badr S, Mohamed G, Lahsen E, Abderrahman A (2011) Étude chimique et biologique des huiles essentielles de Juniperus phoenicea ssp. Lycia et Juniperus phoenicea ssp.turbinata du Maroc. Biotechnol. Agron Soc Environ 15: 415-424.

20. Nakanishi T, lida N, Inatomi Y, Murata H, Inada A, et al. (2005) A monoterpene glucoside and three megastigmane glycosides from Juniperus communis var. depressa. Chem Pharm Bull (Tokyo) 53: 783-787.

21. van Acker SA, van den Berg DJ, Tromp MN, Griffioen DH, van Bennekom WP et al. (1996) Structural aspects of antioxidant activity of flavonoids. Free Radic Biol Med 20: 331-342.

22. Nabavi S, Ebrahimzadeh M, Fazelian M, Eslami B (2009) In vitro Antioxidant and Free radical scavenging activity of Diospyros lotus and Pyrus boisieriana growing in Iran. Mag 4: 122-126.

23. Azlim A, Ahmed J, Syed Z, Mustapha S, Aisyah M, et al. (2010) International Food Research Journal 17: 1077-1084.

24. Afifi FU, Kasabri V (2013) Pharmacological and phytochemical appraisal of selected medicinal plants from jordan with claimed antidiabetic activities. Sc Pharm 81: 889-932.

25. Farjon A (1992) The taxonomy of the multiseed junipers (Juniperus sect Sabina) in southwest Asia and east Africa. Edinb J Bot 49: 251-283.

26. Adams $P$ (2008) Junipers of the World: the genus Juniperus, 2nd Ed.Vancouver BC, Canada: Trafford Publishing 8: 367-371.

27. Mansouri N, Satrani B, Ghanmi M, El Ghadraoui A, Aafi A (2010) Valorisation des huiles essentielles de Juniperus thurifera et de Juniperus oxycedrus du Maroc. Phytothérapie 8: 166-170.

28. Nakanishi T, lida N, Inatomi $\mathrm{Y}$, Murata H, Inada A, et al. (2004) Neolignan and flavonoid glycosides in Juniperus communis var. depressa. Phytochemistry 65 207-213.

29. Nakanishi T (2005) Pair of new atropisomeric cupressuflavone glucosides isolated from Juniperus communis var. depressa. Tetrahedron Lett 46: 65336535.

30. Messaoud R, Takia L, Hafsa S, Azzedine Z, Pierre C, et al. (2013) Antibacteria Activity of Essential oils of Juniperus phoenicea from Eastern Algeria. Journal of Applied Pharmaceutical Science 3: 22-28.

31. Nyangono C, Chakokam N, Kuate 1, Ngondi1 J, Enyong J (2012) Effect of Guibourtia tessmannii extracts on blood lipids and oxidative stress markers in triton WR 1339 and high fat diet induced hyperlipidemic rats. Biology and Medicine 4: 01-09.

32. Malu S, Obochi G, Tawo E, Nyong B (2009) Antibacterial activity and medicina properties of juniperus phoenicea. Global J Pure and Applied Science 15: 365-368.

33. Ekweny U, Elegalam N (2005) Antibacterial activity of juniperus phoenicea extracts on Escherichia coli and Salmonella typhyi. Int J Mol Med Adv Sci 1 411-417.

34. Guynot M, Ramos A, Setó L, Purroy P Sanchis V, et al. (2005) Antifungal activity of volatile compounds generated by essential oils against fung commonly causing deterioration of bakery products. Journal of Applied Microbiology 94: 893-899.

35. Smith A, Stewart J, Fyee L (2001) The potential application of plant essentia oils as natural food preservation in soft cheese. Food Microbiol 18: 463-470.

36. Delaquis PJ, Stanich K, Girard B, Mazza G (2002) Antimicrobial activity of individual and mixed fractions of dill, cilantro, coriander and eucalyptus essential oils. Int J Food Microbiol 74: 101-109. 
Citation: Elmhdwi MF, Attitalla IH, Khan BA (2015) Evaluation of Antibacterial Activity and Antioxidant Potential of Different Extracts from the Leaves of Juniperus Phoenicea. J Plant Pathol Microb 6: 300. doi:10.4172/2157-7471.1000300

Page 8 of 8

37. Burt S (2004) Essential oils: their antibacterial properties and potential applications in foods-a review. Int J Food Microbiol 94: 223-253.

38. Mazari K, Bendinerad N, Benkhechi C, Fernandez X (2010) Chemical Composition and Antimicrobial Activity of Essential Oil Isolated from Algerian Juniperus phoenicea $L$ and Cupressus sempervirens. Medicinal Plants Research 4: 959-964.

39. Ait Ouazzou A, Loran S, Arakrak A, Laglaoui A, Rota C, et al. (2012) Evaluation of the chemical composition and antimicrobial activity of Mentha pulegium
Juniperus phoenicea, and Cyperus longus essential oils from Morocco. Food research international 45: 313-319.

40. El-Sawi S, Motawae H, Amal M (2007) Chemical Composition, Cytotoxic Activity and Antimicrobial Activity of Essential oils of leaves and berries of Juniperus phoenicea. Grown in Egypt. African J of Traditional, Complementary and Alternative Medicines 4: 417-426.

41. Korakot C, Shiow Y, Chien Y, Jingtair S (2006) Effect of natural volatile compounds on antioxidant capacity and antioxidant enzymes in raspberries. Postharvest Biology and Technology 40: 106-115. 